\title{
ADAPTATION OF THE FINE-KINNEY METHOD IN SUPPLY CHAIN RISK ASSESSMENT
}

\author{
ZAHIRA GABRIELA CRUZ NETRO, ELIZABETH DE LA TORRE ROMERO \\ \& JOSE LUIS MARTINEZ FLORES \\ Universidad Popular Autonoma del Estado de Puebla, Instituto Mexicano del Transporte, \\ Universidad Popular Autonoma del Estado de Puebla, Mexico
}

\begin{abstract}
Competitiveness based on the efficient operation of global supply chains requires a reduction of total logistic costs while maintaining them flexible to market changes and unforeseen events. Therefore, the focus on safety remains a key issue within the study of supply chains. Safety (or lack thereof) has an impact on operating costs, delivery time, inventory volume and the value of insurance rates, which can lead to a decrease of international competitiveness. This makes supply chain safety a competitive advantage, source of added value. The present study aims to expose risk factors assessment using an adaptation of the Fine-Kinney method, in which risks are analysed based on their risk exposure, likelihood and impact severity. This adaptation includes an adjustment on the occurrence scale to consider the general degree of incidence, as well as on the severity scale to consider the number of impacts that each risk involves. A risk map for the processes associated with the chain using the scales considered is also proposed. Risks associated to the supply chain of a chemical company located in Mexico are assessed using this methodology, in order to establish the degree of vulnerability of each process involved, as well as to document the existing processes in the mitigation of risks. In the scope of the analysis, a total of 118 risks were found and classified, spotting 14 with a high-risk level. $18.6 \%$ of documented risk mitigation plans were detected, as well as $38.98 \%$ of undocumented plans. This is a first effort on identifying the sources of risk and thus, can be useful to prioritize the mitigation approach towards each one, in order to develop over the long term a risk management process at a corporative level.
\end{abstract}

Keywords: Fine-Kinney method, supply chain risk management, risk assessment.

\section{INTRODUCTION}

Globalized markets and outsourcing of activities minimize the control that companies can exert on the supply chain, since these make them more complex and extensive. Adding difficulties to normal variations on supply and demand, there are also some other issues that, although not directly related to the performance of the chain, can improve or hinder the flow of resources that transit through it. While the focus on risk is not new, the approach to safety remains a significant issue within a supply chain study. Both security and safety have repercussions on operating costs and therefore in its international competitiveness.

There is a growing awareness among companies to minimize the impact of the occurrence that the risks to which they are exposed could have. The first part to achieve a culture in risk management in supply chains, following the determination of the company work on this topic, is to identify the different sources of risk [1] in order to develop strategies to overcome them. It is imperative to find a balance between safety/security and competitiveness, investing resources in safety/security-related issues, affecting the least possible to logistic costs but reducing the vulnerability of supply chains. 


\section{THEORETICAL FRAMEWORK}

\subsection{Risk}

Risk is the probability that a given event (generally negative and undesirable) occurs within a certain time [2]. It focuses mainly on the consequences of the occurrence of such events, which may be failures, accidents, and injuries, among others. It is considered as the function of the probability that an event occurs and the magnitude of its consequences in case of occurrence [3], as show on eqn (1).

$$
\text { Risk Level }=\text { Probability of Occurrence } * \text { Consequence of Occurrence. }
$$

There are two different approaches to risk that complement each other. One of them focuses on ensuring the correct functioning of a specific product/process/procedure, which leads to operating under appropriate conditions to avoid accidents and their consequences. The other approach has to do with the prevention, detection and response to illegal events such as theft, sabotage and unauthorized access, among others. These concepts are safety and security respectively. In other words, safety refers to protection against unintended random incidents, resulting from one or more coincidences, while security is the protection against deliberate incidents resulting from planned acts [4].

\subsubsection{Risk analysis}

A risk analysis can be defined as the study of the possibility and consequences of each risk factor, once identified and classified [5]. It will help determine which factors have to be managed in order to minimize the overall risk impact on the chain. Three approaches (qualitative, quantitative, semi-quantitative) can be used to determine the level of risk, depending on the detail desired and/or the historical information about previous risk events available. Some of these methods are summarized in the following tables.

Table 1: Methodologies for risk analysis (Source: Adapted from Cruz et al [6] and Romero [7]).

\begin{tabular}{|c|c|c|c|c|c|}
\hline \multicolumn{6}{|c|}{ Considered factors in different approaches } \\
\hline \multicolumn{2}{|c|}{ Qualitative } & \multicolumn{2}{|c|}{ Quantitative } & \multicolumn{2}{|c|}{ Semi-quantitative } \\
\hline What if...? & $\begin{array}{c}\text { development of } \\
\text { scenarios }\end{array}$ & \multirow{3}{*}{$\begin{array}{l}\text { Quantitative } \\
\text { Fault Tree } \\
\text { Analysis } \\
\text { (FTA) }\end{array}$} & \multirow{3}{*}{$\begin{array}{c}\text { Existing } \\
\text { preventive } \\
\text { measures for } \\
\text { hypothetical } \\
\text { accidents }\end{array}$} & \begin{tabular}{c|} 
Simple \\
valuation
\end{tabular} & Review of damages \\
\hline $\begin{array}{l}\text { Matrix of risk } \\
\text { factors }\end{array}$ & Detailed identification & & & $\begin{array}{l}\text { Binary } \\
\text { Method }\end{array}$ & $\begin{array}{c}\text { Probability and severity } \\
\text { of occurrence }\end{array}$ \\
\hline $\begin{array}{l}\text { Historical risk } \\
\text { analysis }\end{array}$ & $\begin{array}{c}\text { Information about } \\
\text { incidents and accidents }\end{array}$ & & & \begin{tabular}{|c|}
$\begin{array}{c}\text { Fine-Kinney } \\
\text { Method }\end{array}$ \\
\end{tabular} & $\begin{array}{c}\text { Exposure, likelihood, } \\
\text { scale of risk }\end{array}$ \\
\hline Checklists & $\begin{array}{c}\text { Compliance of } \\
\text { relevant safety aspects }\end{array}$ & Quantitative & $\begin{array}{c}\text { Events to which } \\
\text { the sequential }\end{array}$ & & $\begin{array}{c}\text { Frequency, probability of } \\
\text { occurrence, maximum }\end{array}$ \\
\hline Job safety analysis & $\begin{array}{c}\text { Description of a } \\
\text { specific process to } \\
\text { detect potential risks }\end{array}$ & $\begin{array}{c}\text { Decision Tree } \\
\text { Analysis }\end{array}$ & $\begin{array}{c}\text { processes of } \\
\text { hypothetical } \\
\text { accidents lead }\end{array}$ & Steel Method & $\begin{array}{c}\text { probable loss, number of } \\
\text { people exposed }\end{array}$ \\
\hline $\begin{array}{c}\text { Failure Mode and } \\
\text { Effect Analysis } \\
\text { (FMEA) }\end{array}$ & $\begin{array}{l}\text { Severity rate, } \\
\text { occurrence rate, } \\
\text { detection rate }\end{array}$ & $\begin{array}{l}\text { Quantitative } \\
\text { Analysis of }\end{array}$ & Causes of an & Strohm \& & $\begin{array}{l}\text { Frequency, probability of } \\
\text { occurrence, maximum } \\
\text { probable loss, number of }\end{array}$ \\
\hline $\begin{array}{c}\text { Hazard and } \\
\text { operability } \\
\text { analysis (HAZOP) }\end{array}$ & $\begin{array}{c}\text { Process risks, potential } \\
\text { operating issues }\end{array}$ & $\begin{array}{c}\text { Causes and } \\
\text { Consequences }\end{array}$ & $\begin{array}{l}\text { accident and its } \\
\text { evolution }\end{array}$ & Method & $\begin{array}{c}\text { people exposed, } \\
\text { company's difficulty of } \\
\text { survival }\end{array}$ \\
\hline
\end{tabular}


Of particular note is the use of the Fine-Kinney method, which is widely used for professional risk assessment. It implies that risks can be somehow pondered considering the likelihood, the exposure to the risk and the possible consequences that the incidence of the risk might bring (Kinney [8]). The risk score is a function of the product of the three factors, as presented on eqn (2).

$$
\text { Risk level }=\text { risk exposure } * \text { likelihood } * \text { impact severity. }
$$

The Scales used by the Fine-Kinney's method are the ones shown on Table 4.

Table 2: Scales proposed on the Fine-Kinney method. (Source: Berezutskyi \& Berezutskaya [9].)

\begin{tabular}{|c|c|c|c|c|c|}
\hline \multicolumn{2}{|r|}{ Exposure } & \multicolumn{2}{|r|}{ Likelihood } & \multicolumn{2}{|r|}{ Consequences } \\
\hline 10 & Permanent & 10 & Expectations that happens & 100 & $\begin{array}{l}\text { Catastrophe, many } \\
\text { victims }\end{array}$ \\
\hline 6 & $\begin{array}{l}\text { Regular } \\
\text { (daily) }\end{array}$ & 6 & Very likely & 40 & Alarm few victims \\
\hline 3 & Occasionally & 3 & Unusual, but possible & 15 & $\begin{array}{l}\text { Very heavy, } 1 \\
\text { deceased }\end{array}$ \\
\hline 2 & $\begin{array}{l}\text { Sometimes } \\
\text { (monthly) }\end{array}$ & & Unbelievable & 7 & Heavy, disability \\
\hline 1 & $\begin{array}{l}\text { Sometimes } \\
\text { (annually) }\end{array}$ & 0.5 & $\begin{array}{l}\text { One can imagine but } \\
\text { incredibly }\end{array}$ & 3 & $\begin{array}{l}\text { Serious injury and } \\
\text { absenteeism }\end{array}$ \\
\hline 0.5 & Very rare & 0.2 & Almost impossible & 1 & $\begin{array}{l}\text { Minimum, enough } \\
\text { first aid }\end{array}$ \\
\hline \multirow[t]{2}{*}{0} & Never & 0.1 & Unable & & \\
\hline & & 0 & Absolutely impossible & & \\
\hline
\end{tabular}

Table 3: Risk score interpretation, Fine-Kinney method. (Source: Berezutskyi \& Berezutskaya [9].)

\begin{tabular}{|c|c|}
\hline Risk score & Risk situation \\
\hline$>400$ & Very high risk; consider discontinuing operation \\
\hline $200-400$ & High risk; immediate correction required \\
\hline $70-200$ & Substantial risk; correction needed \\
\hline $20-70$ & Possible risk; attention indicated \\
\hline$<20$ & Risk; perhaps acceptable \\
\hline
\end{tabular}

Once obtained information about risks and their impacts, a risk map can be carried out. This is an instrument that allows locating harmful factors in a given work space [10]. The purpose of risk maps is to implement prevention plans and programs as a priority for those risks with greater impact, to monitor risk management evaluating the effectiveness of the preventive actions implemented and to improve working conditions regarding safety/security.

\subsubsection{Supply chain risk}

The supply chain is the combination of organizations and service providers that manage the supply and manufacture of raw materials, as well as the delivery of finished products from 
the origin to the final customers [11]. In order to achieve an efficient coordination of all the operations required to ensure the supply, manufacture and delivery to the customer fulfilling their requirements, the supply chain management is carried out.

Risk is the result of uncertainty about future events. In a supply chain, this uncertainty has to do with the occurrence of events that may interrupt the flow of materials in the way it was conceived. The more complex the chain is, the more likely it is that events will be affected. Outsourcing operations increase risk within a supply chain, especially if companies providing the outsourced service have not verified their security requirements [12].

Different authors designate different concepts to risk triggers, such as risk types [13], supply chain risk threats [14], or supply chain risk vulnerability constructs (sources, drivers, consequences and mitigating strategies) [15], with their respective proposes of prevention and mitigation. Identification of potential sources of risk and implementation of actions to contain vulnerability are considered supply chain risk management. For mitigating supply chain risk, robustness [16], resilience [17], or a combination of both [18] within supply chain processes is consistently proposed.

To identify supply chain risk, qualitative methods of risk analysis using qualitative [19], or quantitative methods [20], can be applied. Although safety analysis on supply chains has been considered previously, since $9 / 11$ events focus on security had increased its relative importance. Closs and McGarrell [11], for example, elaborate on security by enumerating critical dimensions and requirements for secure supply chains and proposing a tool to evaluate the level of security on companies.

Some other studies focus on the generation of informs that include the situational description of the risk for supply chains, either on a safety or a security point of view as to a country like Mexico in general [21], or a wider zone like Latin America regarding risk on inland supply chains [22]. Organisms as APICS fosters and presents findings on a supply chain risk management survey and compares them with the evolution since 2014 [23]. As an incentive for considering supply chain risk management, Peleg-Gillai et al. [24] shows the inherent benefits of investing on supply chain security that innovative companies report.

\subsubsection{Supply chain risk management}

Supply chain risk management consist on the identification and handling of the different types of risks through a coordinated approach among the stakeholders within it, in order to reduce the total vulnerability of all the processes involved. Khan [25], also says that it is a matter of avoiding the loss of customer trust and the erosion of shareholders' equity as a result of supply chain disruptions.

Focused on security supply chains, the C-TPAT program, part of the U.S. Customs and Border Protection's (CBP) cargo enforcement strategy, developed a risk analysis process [12], focused on terrorism, smuggling of illicit materials and people, organized crime, and conditions that can increase the risk of such threats. Closs and McGarrell [11], propose a methodology for establishing the level of security of a supply chain. For safety on supply chains, Kleindorfer and Saad [20], propose a management system to deal with risk that derive on supply chain disruptions based on statistical analysis of accidents on a chemical industry.

Tummala and Schoenherr [1] developed the Supply Chain Risk Management Process (SCRMP) that provides a conceptual framework for efficiently and effectively managing the risks (on safety and/or security) existent throughout the chain. The complete model is shown in Fig. 1. 


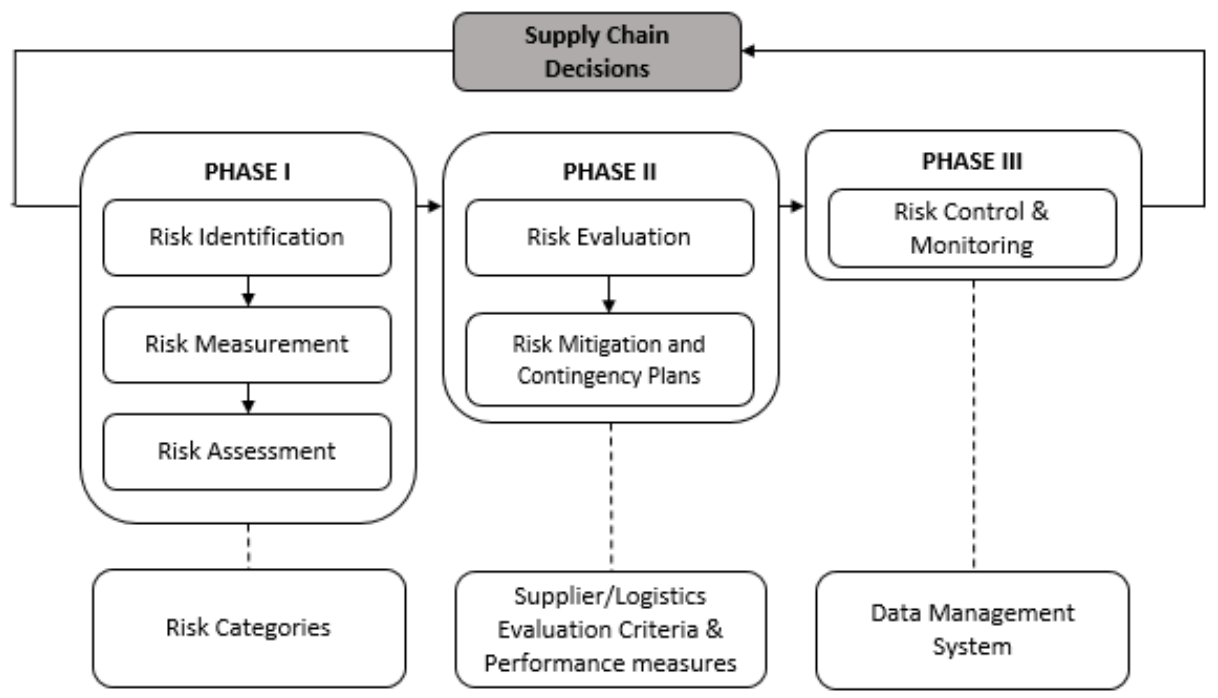

Figure 1: Supply chain risk management process. (Source: Adapted from Tummala \& Schoenherr [1].)

\section{METHODOLOGY}

\subsection{General method}

This paper presents an alternative methodology based on the Fine-Kinney approach for the phase one of the SCRMP [1]. This phase consists on the risk identification, which will be performed by analysing the company's logistics chain, measuring and assessing them, determining their occurrence and the potential impact of the risks for later evaluation.

The process is established as follows:

1. First, key supply chain are identified in the organization that will conduct the study, by mapping the relationships among key areas to understand resource flows through them. In this step, it is important to identify the key personnel involved, since they would be participating on step three of this process.

2. Then, the general instrument proposed is adapted to the organization that will conduct the study. This instrument has been designed to obtain relevant information regarding the risks detected, their impact, recurrence and current process of mitigation.

3. The instrument designed aimed at knowing the different risks of the company. In order to analyse the risk more deeply, besides the base elements of risk exposure, likelihood and impact severity, two other aspects were taken into account.

4. Next, a series of interviews to those involved in controlling the process of the relevant areas detected are applied.

5. An open interview format is suggested. In this, the interviewed person is allowed to delve into the occasional and recurrent detected risks and what has been done to recover from the events occurred, as well as the mitigation plan (if any). The interviews should be of audience by area of study, so the key personnel involved 
could jointly analyse the situations presented. It is an aimed interview that seeks to cover the elements embodied in the instruments described on step 2.

6. The obtained information is processed in order to perform a risk analysis and a risk map, evaluating the degree of vulnerability with which the organization's processes currently count. The analysis is based on the Fine-Kinney method, considering that subjective scales for each aspect have to be adjusted to the specific organization studied. All the aspects considered in the methodology are explained below.

3.2 Subjective scales and other considered aspects

\subsubsection{Risk exposure}

Exposure to risk is expressed as the relation between the existing risk situations and the time during which, one is vulnerable to it [23], as summarized in eqn (3)

$$
\text { Risk Exposure }=\frac{\text { risk situation }}{\text { time of exposure }} \text {. }
$$

\subsubsection{Likelihood}

It is the frequency with which a risk derives on a disruptive event in a process, as shown in eqn (4). The likelihood is determined taking into account the available historical information. In case of not having it, a subjective criterion of occurrence is applied, to which a scale of probability was assigned. This scale must consider the degree of incidence of all the risk detected

$$
\text { Likelihood }=\frac{\text { disruptive event due to a risk }}{\text { risk of exposure }} .
$$

To calculate the scale, subjective criterion for all the risks, even for those with historical information available, has to be obtained in qualitative terms (such as: very frequently, frequently, normal, rare, very rare, never/almost never, for example). There would be some data with both qualitative and historical data. From these, average quantitative values can be inferred in order to meet qualitative description. Once obtained the ranges, the probability average is assigned to those risk that lack of historical information. These last values should be validated by experts in the area where risks are detected.

\subsubsection{Impact severity}

It determines the subjective impact of the occurrence of the risk. In this methodology, severity impact level is considered as an incremental scale of the possible impacts a risk can have, as shown in eqn (5). The occurrence of a risk may have consequences for the organization in one or more of them. Impacts should also be pondered by the relative importance each organization might have

$$
\text { Impact severity }=\frac{\sum_{i=1}^{n}{\text { relative } \text { weight }_{i} * \text { impact }_{i}}_{\text {risk of exposure }}}{\text {. }}
$$

\section{CASE STUDY: CHEMICAL COMPANY}

\subsection{Background}

The proposed methodology was implemented in a chemical company located in Mexico. Since 2008, it manufactures and distributes emulsions, materials for opacifiers, dispersants, 


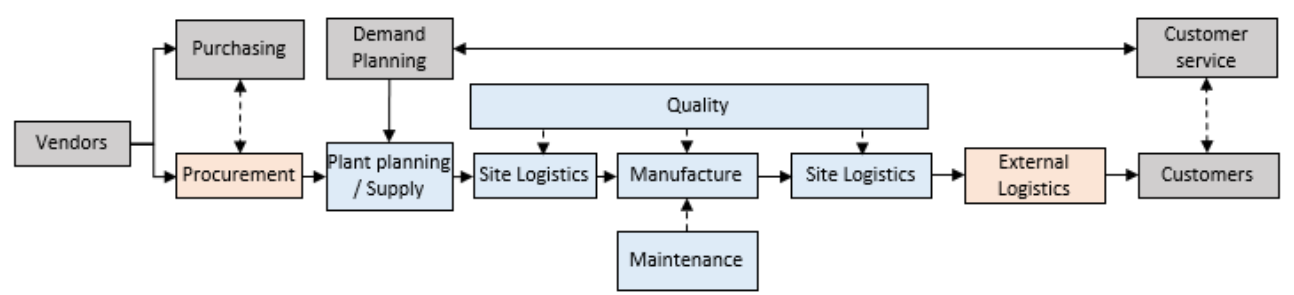

Figure 2: Study scope of the company's supply chain. (Source: Own elaboration.)

biological modifiers, coatings, adhesives and biocides in a mostly local market with an approximate $40 \%$ of export operations to Caribbean and Latin American countries mainly. This enterprise intends to know the most important risks within its supply chain with the purpose of subsequently suggest specific risk management programs for those that represent greater vulnerability according to the impact of the disruptive event triggered by that risk.

The functional supply chain mapping, which includes the identified scope areas, is shown on Fig. 2. A more detailed flow mapping of the logistics of the company's resources was also elaborated.

After instrument adaptation, its application was conducted. A safety analysis was carried out at the workplace where, on the basis of the specific process performed by each area, the potential risk of disruption in the product flow was obtained. Conducting interviews with decision makers introducing What if? technique made it possible to obtain information both from the supply chain process and from the risks detected. The realization of process maps also allowed to glimpse points vulnerable to a disruption. The approach towards a scenario of risk factors allowed a deeply description of the effects of previously detected risks.

When obtaining the information of the instruments, a semi-qualitative analysis was carried out. Risk factors assessment is done using the formulation proposed and its results enable the creation of the risk map of the processes involved. The degree of vulnerability of each process is established by plotting its impact and recurrence. The results are presented in the following section.

\subsection{Subjective scales}

\subsubsection{Risk exposure}

In this particular case, although time of exposition for each risk detected might be calculable, it was presumed that every process has the same time exposure to every risk detected. This first assumption was done considering that the processes are exposed to any risk at any time.

\subsubsection{Likelihood}

The subjective criterion applied for occurrence was calculated as explained on the methodology, assigning subjective probability of the risk occurrence as shown on Table 5 . While collecting the information, it was detected that from the risks identified $30.51 \%$ have not derivate in a disruption event and $29.66 \%$ have solid information about occurrence. It was necessary to assign subjective probability to $39.83 \%$ of the risk detected. 
Table 4: Subjective probability of the risk occurrence. (Source: Own elaboration.)

\begin{tabular}{|c|c|}
\hline Occurrence & Assigned probability \\
\hline Very frequently & $28.57 \%$ \\
\hline Frequently & $22.86 \%$ \\
\hline Normal & $17.14 \%$ \\
\hline Rare & $6.86 \%$ \\
\hline Very rare & $3.43 \%$ \\
\hline Never/almost never & $0.01 \%$ \\
\hline
\end{tabular}

Table 5: Subjective impact of the risk. (Source: Own elaboration.)

\begin{tabular}{|c|c|}
\hline Severity & $\begin{array}{c}\text { Number of impacts of } \\
\text { each risk }\end{array}$ \\
\hline Very low impact & 1 \\
\hline Low impact & 2 \\
\hline High impact & 3 \\
\hline Very high impact & 4 \\
\hline
\end{tabular}

\subsubsection{Impact severity}

The risk is evaluated considering aspects which derive in consequences for the organization. Having revised the literature, these aspects have been grouped in four: economical, when the impact has a repercussion on costs; personnel, when the damages extend to the integrity of human resources; operational, when it origins a variation of the normal process of product flow; and in the image of the company itself, which represents the perception of disruption by the client, society or other direct or indirect participants in the business. When considering these four types of impact, the impact severity of the consequences of a risk is measured according to the following scale, considering that the same importance has been given to all of them.

\subsection{Results}

The number of risks detected were 118, mainly in External Logistics (25.42\%), Site Logistics (17.8\%), Manufacturing (16.1\%) and Quality (15.25\%). Their occurrence impact mostly on the process operation ( $45 \%)$ and costs $(29 \%)$. The most controlled issue is personnel safety (6\%). Of the risks detected, $69.49 \%$ have developed into some disruptive event on average. The proportion by area is shown on Fig. 3.

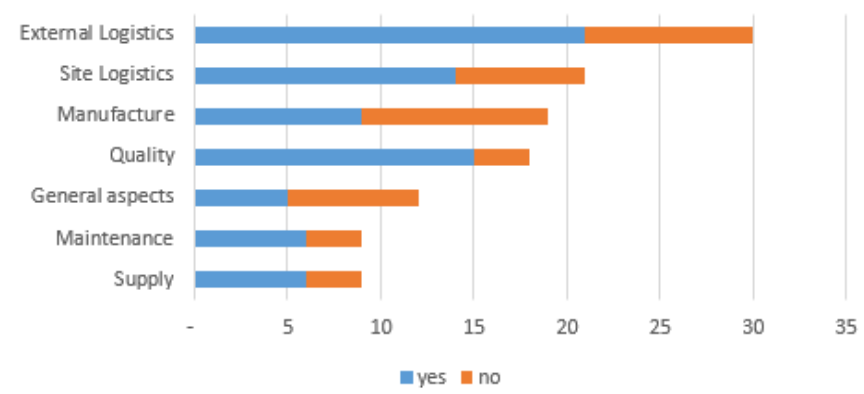

Figure 3: Disruptive events originated by the risk detected. (Source: Own elaboration.) 
The above information only includes exposure to risks. The likelihood and severity previously calculated complements it. Considering the three aspects, it can be observed that the area where the risk can affect the company more by its combination of likelihood/severity of impact is Site Logistics (31.01\%), followed by External Logistics (26.75\%), Quality (18.61\%), and Supply (9.99\%). Manufacture (5.34\%) and Maintenance (2.64\%), despite presenting several risks, their periodicity and impact place them at the last places. This may be due to greater attention to the control of the production process, which reduces the likelihood. All areas have a proportional participation in the potential operational disruption, while External Logistics can have greater economic and image impact, as shown on Fig. 4. This is because External Logistics represents the last link towards the customer and has direct a contact with him in the delivery of the finished goods.

Once information was analysed, the general risk mapping obtained is as follows, where the detected risks can be identified by degree of vulnerability. The limits established for the risk map are obtained considering the previously calculated subjective scale.

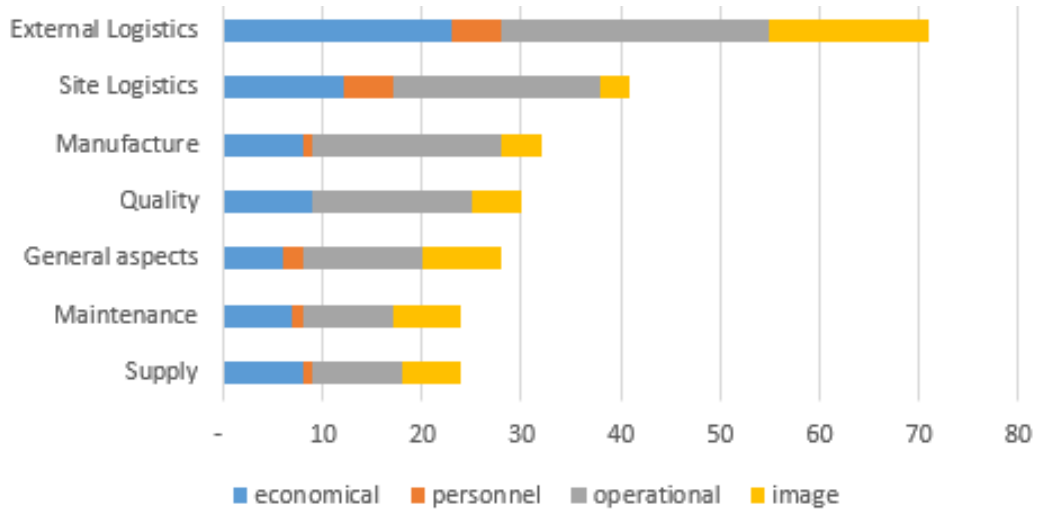

Figure 4: Impact of risks by area. (Source: Own elaboration.)

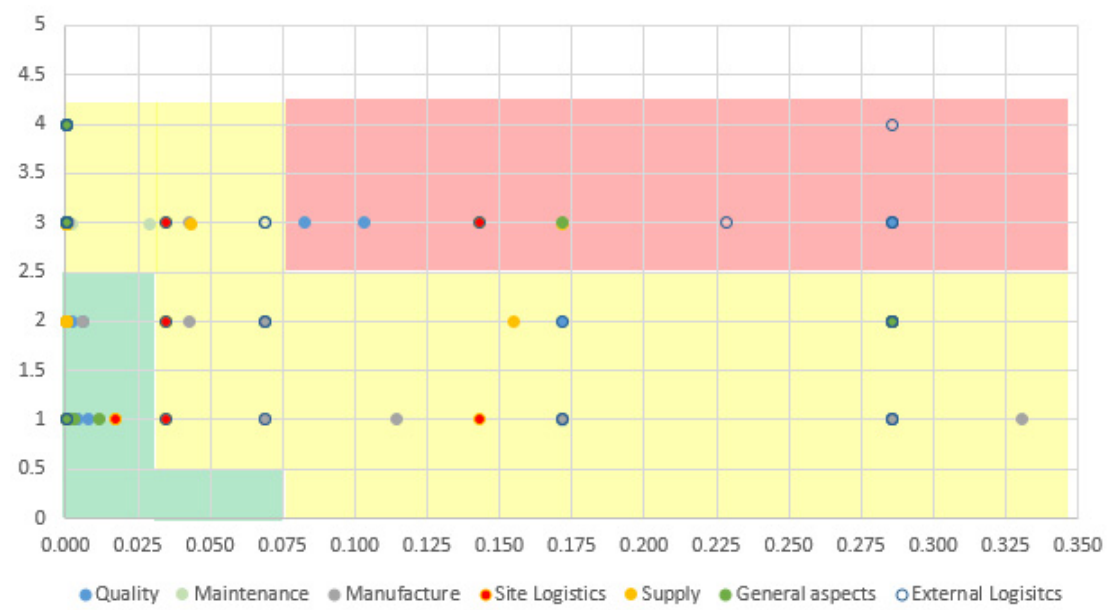

Figure 5: General risk map. (Source: Own elaboration.) 
Table 6: Subjective impact of the risk. (Source: Own elaboration.)

\begin{tabular}{|c|c|c|c|}
\hline & $\begin{array}{c}\text { Number of } \\
\text { risks }\end{array}$ & Risk level** & $\begin{array}{c}\text { Number of risks with } \\
\text { the highest risk level }\end{array}$ \\
\hline Site Logistics & 21 & 6.1010 & 3 \\
\hline External Logistics & 30 & 3.6184 & 4 \\
\hline Quality & 18 & 3.6071 & 5 \\
\hline Supply & 9 & 2.1696 & 1 \\
\hline Manufacturing & 19 & 1.3722 & 0 \\
\hline General aspects & 12 & 0.7581 & 1 \\
\hline Maintenance & 9 & 0.3743 & 0 \\
\hline
\end{tabular}

**Considering exposure, likelihood and impact severity.

Table 6 shows the areas by vulnerability in terms of the potential risks of disruption of the chain. Some control is observed in the Manufacturing process and General Aspects. Supply and Maintenance remain as the least risk level. The areas with the greatest potential for disruption are Site Logistics, Quality and External Logistics, either because of the periodic occurrence of events and/or the direct impact they have on the customers they serve.

\subsubsection{Findings on risk mitigation}

Although $69.49 \%$ of the risks detected have resulted in some kind of disruptive event, it is noteworthy that only $18.64 \%$ have some type of documented mitigation plan. However, informal actions are applied for a considerable percentage $(38.98 \%$ for a total of $57.62 \%$ risk with mitigation plans). There is no plan for $42.37 \%$ of the risks detected. Those areas with the most documented mitigation procedures are Manufacturing, Quality and Site Logistics. Logistics and General Processes stand out like those with the least mitigation plans either documented or undocumented.

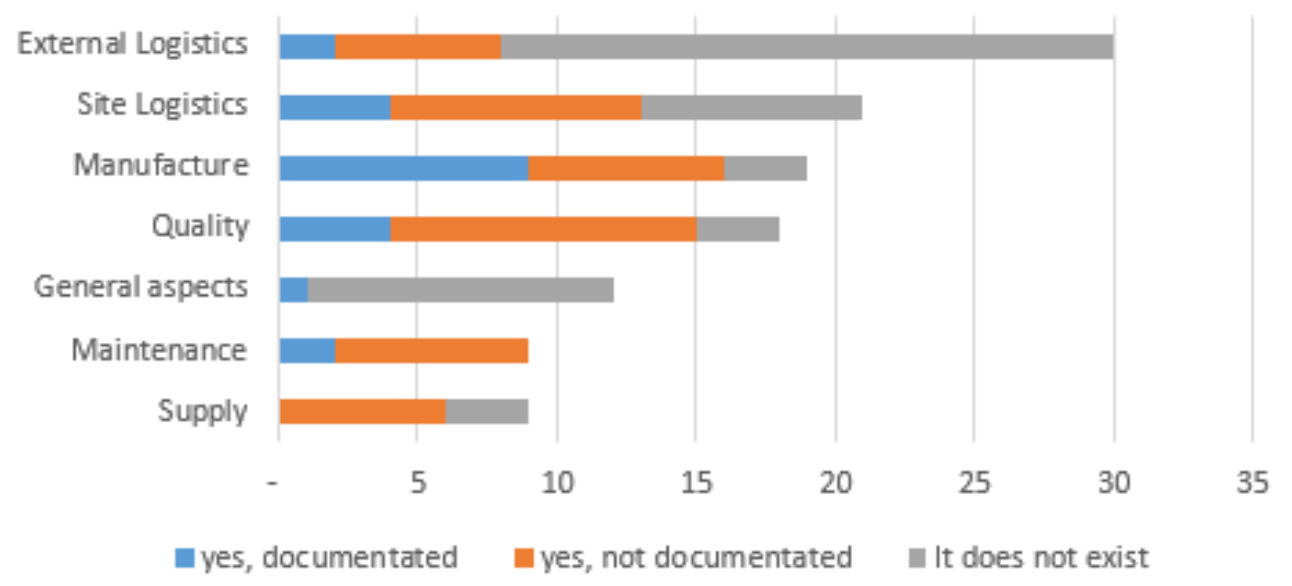

Figure 6: Findings on mitigation plans. (Source: Own elaboration.) 


\section{CONCLUSIONS}

Companies can begin to focus on improving safety in the supply chain by applying their own methodologies or by aligning them with existing methods or regulations, as the proposed adaptation of the Fine-Kinney method did in this case. Knowing the sources of risks and classifying them will allow to prioritize the actions that must be implemented to reduce their consequences, remembering that the logistics chain is as secure as its weakest link.

The first action is to assess the current process by looking at the main actors in the chain and the common sources of risks in the environment in which the business is carried out. This assessment will allow the creation of a map of risks and determine their level of vulnerability. This should not be a one-time process, but the first step to institutionalize an integral risk management program that re-evaluates risks and their consequences on a regular basis.

In the case of study presented, the findings are significant. The areas of Manufacturing and Maintenance are perceived as the most controlled, probably because of the corporate approach to optimizing the key business process. Site Logistics and External Logistics are seen as the most vulnerable to disruption. This may be due to the proximity of the External Logistics area to the customers, which increases the impact towards them or the direct and frequent involvement of Site Logistics in the process. It is not surprising then that four risks detected on External Logistics and three of Site Logistics are categorised as most vulnerable. Regarding mitigation plans, it was detected that the company has $18.6 \%$ documented mitigation plans (most of them for the areas of Manufacturing, Quality and Site Logistics), $38.98 \%$ of undocumented plans and $42.4 \%$ without any plans for the risks detected (mainly in the areas of External Logistics and General Processes).

The next step following the identification of the sources and the prioritization of these sources, should be the development of risk management plans and their implementation. These strategies for planning, mitigation, detection, response and recovery must focus on the awareness of the participating actors throughout the chain on developing a culture of prevention and action management of risk. This represents the future work to be developed at each area and at the whole company, then, best practices could be also replicated in an intercompany implementation.

It is important to establish a solid basis for supply chain risk detection and assessment. From these first approaches, it will depend that future endeavour to mitigate them will accomplish expectations. One of the actions that has proven to work for identification and prevention of impact of risks is to maintain a collaborative supply chain. Good suppliercustomer relationships facilitate communication and joint work to deal with disruptive situations. Coordinated actions between all the actors within the supply chain turn out to be the most effective and sustainable over time.

[1] Tummala, R. \& Schoenherr T et al., Assessing and managing risks using the Supply Chain Risk Management Process (SCRMP). Supply Chain Management: An International Journal, 16 (6), pp. 474-483, 2011. doi: 10.1108/13598541111171165.

[2] Pico Merchan, M., Metodología de los panoramas de los factores de riesgo ocupacional: estrategia educativa en salud ocupacional. Hacia la promoción de la salud, 6, pp. 17-24, 2001.

[3] Contelles Díaz, E.A., Emergencias: aplicaciones básicas para la elaboración de un manual de autoprotección. Marcombo S.A. Barcelona, Spain, 2010.

[4] Albrechtsen, E., Security vs safety. Norwegian University of Science and Technology, Department of Industrial Economics and Technology Management, 2003. 
[5] Comunidad de Madrid. Análisis y cuantificación del riesgo. http://www.madrid.org/cs/StaticFiles/Emprendedores/Analisis_Riesgos/pages/pdf/me todologia/4AnalisisycuantificaciondelRiesgo(AR)_es.pdf. Accessed on: 16 Aug, 2016.

[6] Cruz Netro, Z., Medina Álvarez, J., Meza Morales, M. \& Vázquez Fernández, J., Estimación de riesgos en una Institución de Educación Superior: Caso UPALT. Revista Administración \& Finanzas, 2(2), pp. 228-240, 2015.

[7] Romero, J.C.R., Métodos de evaluación de riesgos laborales. Ediciones Díaz de Santos. Madrid, Spain, 2004.

[8] Kinney, G.F., Practical risk analysis for safety management. China Lake, CA: Naval Weapons Center, 1976.

[9] Berezutskyi, V. \& Berezutskaya, N., Indicators in risk management. National Technical University of Kharkov, Ukraine, pp. 108-116, repository.kpi.kharkov.ua. 2015.

[10] Jakobsen, N., Mapa de riesgos: Definición. Calidad, seguridad laboral e higiene. Online https://seguridadybioseguridad.wordpress.com/2010/05/04/mapa-de-riesgosdefinicion/. Accessed on: 16 Aug. 2016.

[11] Closs, D.J. \& McGarrell, E.F., Enhancing security throughout the supply chain. IBM Centre for the Business of Government Special Report Series. Washington, DC, 2004.

[12] Dirección de Impuestos y Aduanas Nacionales DIAN (2015). C-TPAT Análisis de Riesgos en 5 Pasos. Guía de procedimientos. Online http://www.dian.gov.co/ descargas/operador/documentos/2015/Analisis_de_Riesgo_En_5_Pasos.pdf. Accessed on: 16 Aug. 2016.

[13] Cid Delancer, S., Riesgos Latentes en la Cadena de Suministros. Online https://www.eoi.es/blogs/sergioeliascid/2011/11/06/riesgos-latentes-en-la-cadena-desuministros/. Accessed on: 16 Aug. 2016.

[14] Ekwall, D., Supply Chain Security-Threats and Solutions. INTECH Open Access Publisher, 2013.

[15] Jüttner, U., Peck, H. \& Christopher, M., Supply chain risk management: outlining an agenda for future research. International Journal of Logistics: Research and Applications, 6(4), pp.197-210, 2003.

[16] Tang, C.S., Robust strategies for mitigating supply chain disruptions. International Journal of Logistics: Research and Applications, 9(1), pp. 33-45, 2006. doi: 10.1080/13675560500405584

[17] Christopher, M. \& Peck, H., Building the resilient supply chain. The International Journal of Logistics Management, 15(2), pp.1-14, 2004.

[18] Sheffi, Y. \& Rice Jr, J.B., A supply chain view of the resilient enterprise. MIT Sloan Management Review, 47(1), pp. 41-48, 2005.

[19] Chopra, S. \& Sodhi, M.S., Managing risk to avoid supply-chain breakdown. MIT Sloan Management Review, 46(1), pp.53-61, 2004.

[20] Kleindorfer, P.R. \& Saad, G.H., Managing disruption risks in supply chains. Production and Operations Management, 14(1), pp.53-68, 2005.

[21] Cedillo-Campos, M., Primera encuesta nacional Evaluación del Riesgo en Cadenas de Suministro. Consejo Nacional de Ciencia y Tecnología Reporte de Investigación GC, pp. 74-78, 2011, Mexico, 2011.

[22] Pérez-Salas G., Seguridad de la cadena logística terrestre en América Latina. Serie Recursos Naturales e Infraestructura N 161, CEPAL, Naciones Unidas, 2013.

[23] Campos Cortés, J., Administración del Riesgo dentro de la Cadena de Suministro. Apics.org.mx. Mexico, 2016. 
[24] Peleg-Gillai, B., Bhat, G. \& Sept, L., Innovators in supply chain security: better security drives business value. The Manufacturing Innovation Series, pp. 1-33. Manufacturing Institute, Washington D.C., 2006.

[25] Khan, O., Gestión de los Riesgos de la Cadena de Suministro. Más allá del concepto lean-Redacción de los riesgos de la cadena de suministro global. Handbook for Supply Chain Risk Management. Hull University Business School, UK, 2010. 